\title{
Assessing quadriceps muscle strength as a tool to determine the approach to and prognosis in COPD patients
}

\author{
Avaliação da força do quadríceps como ferramenta para se estabelecer a \\ conduta e o prognóstico em pacientes com DPOC
}

\section{Luciana Dias Chiavegato ${ }^{1,2}$}

In a recent systematic review, Evans et al. ${ }^{(1)}$ compared 728 COPD patients with 440 healthy individuals in terms of quadriceps endurance. The authors found that, in fact, quadriceps endurance was reduced in the COPD patients, regardless of the task measured or requested. Muscle dysfunction, which is present in COPD patients, manifests among other ways as deficits in peripheral muscle strength, affecting upper limb muscles and, more specifically, the quadriceps muscle. ${ }^{(2,3)}$ These losses culminate in worsened functioning and worsened activities of daily living, when thinking of upper limbs, and in decreased physical fitness, when thinking of lower limbs, which leads to impaired quality of life. ${ }^{(2-4)}$ Muscle dysfunction is also prominent in various other lung diseases, such as bronchiectasis, ${ }^{(5)}$ cystic fibrosis, ${ }^{(6)}$ idiopathic pulmonary fibrosis, ${ }^{(7)}$ etc. However, although muscle dysfunction is widely addressed, until quite recently, the equations used for the Brazilian population, as well as the predictive values, were those derived from distinct populations.

In this issue of the JBP, Nellessen et al., ${ }^{(8)}$ in a study involving 56 COPD patients, elegantly compared the characteristics of and assessed agreement among three different equations for predicting peak quadriceps muscle force-those of Neder et al.,(9) Decramer et al., ${ }^{(10)}$ and Seymour et al. ${ }^{(11)}$-which take into consideration factors such as age, weight, gender, and even fat-free mass. ${ }^{(9-11)}$ In this study, ${ }^{(8)}$ the authors sought to bring the applicability and comparison of the equations as much as possible into line with the situation in Brazil, such as by assessing body composition by bioelectrical impedance and by measuring knee extensor muscle strength with a hand-held dynamometer. The authors concluded that, even though there is no clearly established cut-off point, no fixed value, for determining the degree of quadriceps muscle weakness, the equations were statistically equivalent, although the equation proposed by Neder et al..$^{(9)}$ gave higher peak force values and showed greater agreement with the other two equations studied.

It is of utmost importance to highlight the clinical relevance of this article ${ }^{(8)}$ for professionals working with patients with lung disease, as well as highlighting that predictive equations for estimating six-minute walk distance, ${ }^{(12-14)}$ shuttle walk distance, ${ }^{(15)}$ and respiratory muscle strength (maximal inspiratory and expiratory pressures) are already available, ${ }^{(16,17)}$ the study by Nellessen et al. ${ }^{(8)}$ has come to compose this scenario. In addition to facilitating the comparison of our data with those by the international scientific community, this will allow us in the near future to propose multicenter studies with an excellent sample size: the Brazilian population.

Undertaking to assess COPD patients for physical fitness, functioning, and activities of daily living is not an easy task. ${ }^{(18)}$ For this reason, we should always rely on studies that consistently present predictive equations and reference values that can guide us in proposing new therapeutic interventions to such patients. ${ }^{(3,4)}$

Culturally, we have some difficulty in citing studies of the Brazilian population. In contrast, it is increasingly important today that national journals enjoy greater visibility. Therefore, here is an invitation: appreciate and make use not only of the articles featured by the JBP, but also of those featured by other national journals. 1 am sure that you will find excellent approaches and data that can be useful in your future studies.

\section{References}

1. Evans RA, Kaplovitch E, Beauchamp MK, Dolmage TE, Goldstein RS, Gillies CL, et al. S. Is quadriceps endurance reduced in COPD? a systematic review.

1. Programa de Mestrado e Doutorado em Fisioterapia, Universidade Cidade de São Paulo, São Paulo, Brasil.

2. Programa de Residência Multiprofissional com Concentração em Distúrbios Respiratórios Clínicos e Cirúrgicos, Universidade Federal de São Paulo, São Paulo, Brasil. 
Chest. 2015;147(3):673-84. http://dx.doi.org/10.1378/ chest.14-1079

2. Miranda EF, Malaguti C, Corso SD. Peripheral muscle dysfunction in COPD: lower limbs versus upper limbs. J Bras Pneumol. 2011;37(3):380-8. http://dx.doi.org/10.1590/ S1806-37132011000300016

3. Maltais F, Decramer M, Casaburi R, Barreiro E, Burelle Y, Debigaré R, et al. An official American Thoracic Society/ European Respiratory Society statement: update on limb muscle dysfunction in chronic obstructive pulmonary disease. Am J Respir Crit Care Med. 2014;189(9):15-62. http://dx.doi.org/10.1164/rccm.201402-0373ST

4. Barreiro E, Bustamante V, Cejudo P, Gáldiz JB, Gea J, de Lucas P, Martínez-Llorens J, Ortega F, Puente-Maestu L, Roca J, Rodríguez-González Moro JM. Recommendations for the Evaluation and Treatment of Muscle Dysfunction in Patients With Chronic Obstructive Pulmonary Disease. Arch Bronconeumol. 2015 Jun 10. [Epub ahead of print] http://dx.doi.org/10.1016/j.arbr.2015.04.027

5. van Zeller M, Mota PC, Amorim A, Viana P, Martins P, Gaspar L, et al. Pulmonary rehabilitation in patients with bronchiectasis: pulmonary function, arterial blood gases, and the 6-minute walk test. J Cardiopulm Rehabil Prev. 2012;32(5):278-83. http://dx.doi.org/10.1097/ HCR.0b013e3182631314

6. Burtin C, Van Remoortel H, Vrijsen B, Langer D, Colpaert K, Gosselink R, et al. Impact of exacerbations of cystic fibrosis on muscle strength. Respir Res. 2013;14:46. http://dx.doi.org/10.1186/1465-9921-14-46

7. Mendoza L, Gogali A, Shrikrishna D, Cavada G, Kemp SV, Natanek SA, et al. Quadriceps strength and endurance in fibrotic idiopathic interstitial pneumonia. Respirology. 2014;19(1):138-43. http://dx.doi.org/10.1111/resp.12181

8. Nellessen AG, Donária L, Hernandes NA, Pitta F. Analysis of three different equations for predicting quadriceps femoris muscle strength in patients with COPD. J Bras Pneumol. 2015;41(4):305-312.

9. Neder JA, Nery LE, Shinzato GT, Andrade MS, Peres C, Silva AC. Reference values for concentric knee isokinetic strength and power in nonathletic men and women from 20 to 80 years old. J Orthop Sports Phys Ther. 1999;29(2):116-26. http://dx.doi.org/10.2519/ jospt.1999.29.2.116
10. Decramer M, Gosselink R, Troosters T, Verschueren M, Evers G. Muscle weakness is related to utilization of health care resources in COPD patients. Eur Respir J. 1997;10(2):447-23. http://dx.doi.org/10.1183/09031 936.97.10020417

11. Seymour JM, Spruit MA, Hopkinson NS, Natanek SA, Man WD, Jackson A, et al. The prevalence of quadriceps weakness in COPD and the relationship with disease severity. Eur Respir J. 2010;36(1):81-8. http://dx.doi. org/10.1183/09031936.00104909

12. Soaresa MR, Pereira CA. Six-minute walk test: reference values for healthy adults in Brazil. J Bras Pneumol. 2011;37(5):576-83. http://dx.doi.org/10.1590/ S1806-37132011000500003

13. Dourado VZ, Vidotto MC, Guerra RL. Reference equations for the performance of healthy adults on field walking tests. J Bras Pneumol. 2011;37(5):607-14. http://dx.doi. org/10.1590/S1806-37132011000500007

14. Britto RR, Probst VS, de Andrade AF, Samora GA, Hernandes NA, Marinho PE, et al. Reference equations for the six-minute walk distance based on a Brazilian multicenter study. Braz J Phys Ther. 2013;17(6):556-63. http://dx.doi.org/10.1590/S1413-35552012005000122

15. Dourado VZ, Guerra RL, Tanni SE, Antunes LC, Godoy 1. Reference values for the incremental shuttle walk test in healthy subjects: from the walk distance to physiological responses. J Bras Pneumol. 2013;39(2):190-7. http:// dx.doi.org/10.1590/S1806-37132013000200010

16. Neder JA, Andreoni S, Lerario MC, Nery LE. Reference values for lung function tests. 11. Maximal respiratory pressures and voluntary ventilation. Braz J Med Biol Res. 1999;32(6):719-27. http://dx.doi.org/10.1590/ s0100-879x1999000600007

17. Pessoa IM, Houri Neto M, Montemezzo D, Silva LA, Andrade AD, Parreira VF. Predictive equations for respiratory muscle strength according to international and Brazilian guidelines. Braz J Phys Ther. 2014;18(5):410-8. http:// dx.doi.org/10.1590/bjpt-rbf.2014.0044

18. Amorim PB, Stelmach R, Carvalho CR, Fernandes FL, Carvalho-Pinto RM, Cukier A. Barriers associated with reduced physical activity in COPD patients. J Bras Pneumol. 2014;40(5):504-12. http://dx.doi.org/10.1590/ S1806-37132014000500006 